\title{
Penggunaan Media Sketsa dalam Meningkatkan Perkembangan Bahasa Anak Usia 5-6 Tahun
}

\author{
DESI SUKENTI* \\ SILVIA** \\ *Fakultas Ilmu Keguruan dan Pendidikan (FKIP) Universitas Islam Riau (UIR) \\ Jl. Kaharuddin Nasution, No. 113, Perhentian Marpoyan, Kota Pekanbaru \\ e-mail: dsukenti@rocketmail.com. HP: 081371539122
}

\author{
**Sekolah Tinggi Keguruan dan Ilmu Pendidikan (STIKIP) Aisyah Riau \\ Jl. Angkasa no. 12 Payung Sekaki, kota Pekanbaru
}

\begin{abstract}
Abstrak: Penelitian ini dilatarbelakangi oleh masih rendah nya kemampuan berbahasa anak Taman Kanak-Kanak Islam Bina Insan Kamil Kecamatan Bukit Raya Pekanbaru, hal ini dapat diketahui dari hasil pengamatan pada data awal kemampuan bahasa anak adalah belum berkembang yaitu sebanyak 59,8\% dengan arti kata kemampuan bahasa anak masih rendah. Perumusan masalah dalam penelitian ini adalah apakah penggunaan media sketsa dapat meningkatkan perkembangan bahasa anak Usia 5-6 Tahun di Taman KanakKanak Islam Bina Insan Kamil Kecamatan Bukit Raya Pekanbaru? Penelitian ini bertujuan untuk mengetahui penggunaan media sketsa dapat meningkatkan perkembangan bahasa anak Usia 5-6 Tahun di Taman Kanak-Kanak Islam Bina Insan Kamil Kecamatan Bukit Raya Pekanbaru. Metode yang digunakan dalam penelitian ini adalah penelitian tindakan kelas (Classroom Action Research) dengan jumlah sampel anak sebanyak 23 orang anak. Teknik pengumpulan data pengumpulan data dalam penelitian ini adalah observasi dan dokumentasi. Teknik analisis data yang digunakan dalam penelitian ini adalah teknik persentase. Hasil penelitian yang dilakukan, Perkembangan bahasa Anak Usia 5 - 6 Tahun di Taman Kanak-Kanak Islam Bina Insan Kamil Kecamatan Bukit Raya Pekanbaru dapat ditingkatkan dengan media sketsa Perkembangan bahasa Anak Usia 5 - 6 Tahun di Taman Kanak-Kanak Islam Bina Insan Kamil Kecamatan Bukit Raya Pekanbaru pada data awal diperoleh skor 278 dengan persentase 37.8\%, pada siklus I memperoleh skor 475 (64,5\%) dengan kiteria mulai berkembang. Terjadi peningkatan Perkembangan bahasa pada anak usia 5-6 tahun pada siklus II dengan skor 556 (75,5\%) dengan kiteria berkembang sangat baik.
\end{abstract}

Kata Kunci: Media Sketsa, Perkembangan Bahasa Anak

\section{PENDAHULUAN}

Anak adalah sebuah pribadi yang unik. Dunia mereka adalah dunia bermain dan senang-senang. Pembelajaran yang disampaikan pada anakanak mestinya juga merupakan pembelajaran yang menyenangkan dengan tanpa melupakan konsep bermain. Selain membutuhkan pendekatan dan metode yang tepat, pembelajaran untuk anak-anak juga membutuhkan alat-alat peraga.

Masa anak-anak adalah masa yang penting untuk menyesuaikan diri 
dengan lingkungan bagi perkembangan dan pertumbuhan anak. Pada diri anak memiliki karakteristik yang unik. Karena pada diri anak mempunyai perbedaan antara anak yang satu dengan yang lain. Pendidikan anak usia dini merupakan proses pembelajaran dengan menggunakan perinsip "bermain sambil belajar atau belajar seraya bermain" yang sesuai dengan karakteristik dan aspek perkembangan anak usia dini. Salah satu metode pembelajaran yang baik adalah menggunakan media sketsa.

Salah satu aspek perkembangan yang ingin dicapai oleh anak usia dini adalah aspek kemampuan berbahasa. Kemampuan ini diperlukan sebagai dasar bagi anak untuk berinteraksi dengan orang lain, baik dengan teman seusianya maupun dengan orang lebih dewasa dari segi umurnya.

Dalam berkomunikasi, bahasa merupakan alat yang penting bagi setiap orang. Melalui berbahasa seseorang atau anak akan dapat mengembangkan kemampuan bergaul (social skill) dengan orang lain. Penguasaan keterampilan bergaul dalam lingkungan sosial dimulai dengan penguasaan kemampuan berbahasa. Tanpa bahasa seseorang tidak akan dapat berkomunikasi dengan orang lain. Anak dapat mengekspresikan pikirannya menggunakan bahasa sehingga orang lain dapat menangkap apa yang dipikirkan oleh anak. Komunikasi antar anak dapat terjalin dengan baik dengan bahasa sehingga anak dapat membangun hubungan sehingga tidak mengherankan bahwa bahasa dianggap sebagai salah satu indikator kesuksesan seorang anak. Anak yang dianggap banyak berbicara, kadang merupakan cerminan anak yang cerdas.

Media sketsa merupakan salah satu cara yang dapat digunakan dalam meningkatkan perkembangan bahasa anak. Sketsa adalah gambar sederhana atau draf kasar yang melukiskan bagianbagian pokok tanpa detail. Dalam menggunakan sketsa, pengajar dapat menuangkan ide-ide ke dalam bentuk gambar sederhana atau draf kasar, yang dapat digunakan dalam proses pembelajaran.

Dalam berkomunikasi, bahasa merupakan alat yang penting bagi setiap orang. Melalui berbahasa seseorang atau anak akan dapat mengembangkan kemampuan bergaul dengan orang lain. Penguasaan keterampilan bergaul dalam lingkungan sosial dimulai dengan penguasaan kemampuan berbahasa. Tanpa bahasa seseorang tidak akan dapat berkomunikasi dengan orang lain. Anak dapat mengekspresikan pikirannya menggunakan bahasa sehingga orang lain dapat menangkap apa yang dipikirkan oleh anak. Komunikasi antar anak dapat terjalin dengan baik dengan bahasa sehingga anak dapat membangun hubungan sehingga tidak mengherankan bahwa bahasa dianggap sebagai salah satu indikator kesuksesan seorang anak. Anak yang dianggap banyak berbicara, kadang merupakan cerminan anak yang cerdas.

Perkembangan bahasa anak TK masih bersifat egosentrik dan self ekspressive yang segala sesuatu masih berorientasi pada dirinya sendiri. Pada masa TK anak menguasai kemampuan berbahasa yang menonjol yaitu pengajuan kalimat tanya. Pada usia enam tahun anak mulai aktif menggunakan gesture atau bahasa gerak dan isyarat. Anak TK dapata menggerakkan anggota tubuh untuk membantu memperjelas maksud perkataannya (Musfiroh, 2008:8).

Berdasarkan hasil pengamatan penulis di Taman Kanak-Kanak Islam Bina Insan Kamil Kecamatan Bukit Raya Pekanbaru, ditemukan ternyata kemampuan bahasa anak adalah belum 
berkembang sebanyak 59,8\% dengan arti kata kemampuan bahasa anak masih rendah.

Di samping itu gurupun mengajar belum menggunakan media, sebagai bukti ketika guru mengajar bahasa guru hanya bercerita saja tanpa melihatkan bendanya atau alat peraga. Anak - anak kurang konsentrasi dalam belajar bahasa hal ini terlihat sewaktu guru mengajar anak tidak memperhatikan pelajaran dan anak sering keluar masuk kelas.

Sebagai seorang guru harus berusaha semaksimal mungkin untuk memperbaiki cara mengajar sehingga anak mampu berbahasa dengan demikian saya akan menggunakan media sketsa. Karna sketsa adalah gambar sederhana atau draf kasar yang melukiskan bagian - bagian pokok tanpa detail. Dalam menggunakan media sketsa, pengajar dapat menuangkan ideide ke dalam bentuk gambar sederhana atau draf kasar, yang dapat digunakan dalam proses pembelajaran. Apabila ditampilkan dengan gambar yang menarik perhatian anak sehingga keingintahuan dan sifat penasaran anak semakin meningkat. Pada akhirnya anak akan sering bertanya dan menjawab pertanyaan yang diberikan guru.

Alat peraga merupakan sarana yang sangat efektif untuk menunjang keberhasilan belajar anak. Oleh karena itu, perlu mempersiapkan alat-alat peraga untuk mempersiapkan alat-alat peraga untuk mempermudah melakukan pengajaran, dan mempermudah anak memahami materi pelajaran.

Oleh karena itu peneliti dirasa perlu mengadakan penelitian tindakan kelas dengan judul "Penggunaan Media sketsa dalam meningkatkan Perkembangan Bahasa Anak Usia 5-6 Tahun Di Taman Kanak-Kanak Islam Bina Insan
Kamil Kecamatan Bukit Raya Pekanbaru".

\section{KONSEP TEORI \\ Perkembangan Bahasa}

Kemampuan berbahasa anak di usia TK merupakan salah satu dari sekian banyak kemampuan anak yang berkembang pesat pada usia ini. Hal ini karena perkembangan anak ditandai dengan masa peka terutama dalam hal perkembangan bahasa. Masa peka inilah yang kemudian akan sangat mempengaruhi perkembangan pada masa selanjutnya. Jika masa peka kemampuan berbahasa ini terlewatkan begitu saja, maka orangtua akan mengalami kesulitan untuk mewujudkan anak dengan kemampuan berbahasa yang optimal.

Berdasarkan pendapat-pendapat di atas, dapat dijelaskan bahwa bahasa merupakan sarana untuk saling berkomunikasi, saling berbagi pengalaman, saling belajar dari yang lain dan untuk meningkatkan kemampuan intelektual. Hal ini berarti bahwa bahasa memiliki peran yang penting bagi manusia. Dengan demikian, dapat dimaklumi jika pada usia dini aspek perkembangan bahasa selalu mendapatkan perhatian.

Lebih lanjut Tarigan (2001:10) Bahasa merupakan suatu bentuk ungkapan yang bentuk dasarnya ujaran atau suatu ungkapan dalam bentuk bunyi ujaran. Bahasa merupakan alat komunikasi dan interaksi yang sangat penting bagi manusia. Melalui bahasa mendapatkan beberapa informasi penting. Bahasa sebagai alat untuk menyampaikan gagasan, pikiran, pendapat, dan perasaan. Oleh karena itu, bahasa sangat penting peranannya bagi kehidupan manusia.

Pembelajaran bahasa Indonesia di sekolah diarahkan untuk meningkatkan 
kemampuan siswa dalam berkomunikasi dengan bahasa Indonesia baik secara lisan maupun tulisan. Untuk mewujudkannya maka pelajaran bahasa Indonesia diprogramkan untuk mengembangkan pengetahuan, sikap positif terhadap bahasa Indonesia dan keterampilan berbahasa. Adapun keterampilan berbahasa dalam kurikulum terdiri atas empat aspek, yaitu keterampilan menyimak, keterampilan berbicara, keterampilan membaca dan keterampilan menulis.

Menurut Santosa (2006:1.2) mengemukakan bahwa bahasa yang dalam bahasa Inggrisnya disebut dengan language berasal dari bahasa latin yang berarti "lidah". Lidah merupakan alat ucap yang paling sering digunakan daripada alat ucap yang lain. Secara universal bahasa ialah suatu bentuk ungkapan yang bentuk dasarnya ujaran. Ujaran inilah yang membedakan manusia dengan mahluk lainnya. Dengan ujaran inilah manusia mengungkapkan hal yang nyata atau tidak, yang berwujud maupun yang kasat mata, situasi dan kondisi yang lampau, kini, maupun yang akan datang. Ujaran manusia itu menjadi bahasa apabila dua orang manusia atau lebih menetapkan bahwa seperangkat bunyi itu memiliki arti yang serupa.

Lebih lanjut Santosa (2006:1.2) mengemukakan bahwa bahasa merupakan alat komunikasi yang mengandung beberapa sifat yakni, sistematik, mana suka, ujar, manusiawi dan komunikatif. Disebut sistematik karena bahasa diatur oleh sistem. Setiap bahasa mengandung dua sistem, yaitu sistem bunyi dan sistem makna.

Sumiati dalam Bachri (2005:106) mengemukakan bahwa bahasa ialah ucapan, pikiran dan perasaan seseorang yang teratur dan digunakan sebagai alat komunikasi antar anggota masyarakat.
Maksudnya bahasa merupakan alat untuk menyampaikan ide atau gagasan yang ada dalam pikiran dan perasaan untuk disampaikan kepada orang lain dengan tujuan agar ide dan gagasan tersebut dipahami bersama. Pemahaman yang dimaksud bukan berbentuk dipahaminya maksud berkomunikasi namun baru pada tahap dipahaminya maksud berkomunikasi namun baru pada tahap dipahaminya ide atau gagasan yang disampaikan.

$$
\text { Menurut Depdiknas (2007:3) }
$$

bahasa merupakan alat komunikasi utama bagi seorang anak untuk mengungkapkan berbagai keinginan maupun kebutuhannya. Anak-anak yang memiliki kemampuan berbahasan yang baik umumnya memiliki kemampuan dalam mengungkapkan pikiran, perasaan serta tindakan interaktif dengan lingkungannya.

Berdasarkan pendapat-pendapat di atas, dapat dijelaskan bahwa bahasa merupakan sarana untuk saling berkomunikasi, saling berbagi pengalaman, saling belajar dari yang lain dan untuk meningkatkan kemampuan intelektual. Hal ini berarti bahwa bahasa memiliki peran yang penting bagi manusia. Dengan demikian, dapat dimaklumi jika pada usia dini aspek perkembangan bahasa selalu mendapatkan perhatian.

\section{Fungsi bahasa Anak}

Sebagaimana telah dikemukakan bahwa bahasa merupakan alat untuk menyampaikan ide atau gagasan yang ada dalam pikiran dan perasaan untuk disampaikan kepada orang lain dengan tujuan agar ide dan gagasan tersebut dipahami bersama. Dengan demikian melalui bahasa orang dapat menyampaikan maksud atau pikirannya pada orang lain. 
Sebagaimana dikemukakan oleh Santosa (2007:1.5) beberapa fungsi bahasa antara lain: (a) Fungsi informasi yaitu untuk menyampaikan informasi timbal balik antara anggota keluarga mapun anggota masyarakat. Berita, pengumuman, petunjuk pernyataan lisan, ataupun tulisan melalui media masa ataupun elektronik merupakan wujud fungsi bahasa sebagai fungsi informasi; (b) Fungsi Ekspresi yaitu untuk menyalurkan perasaan, sikap, gagasan, emosi atau tekanan-tekanan perasaan pembicara; (c) Fungsi adaptasi dan integrasi yaitu untuk menyesuaikan dan membaurkan diri dengan anggota masyarakat. Melalui bahasa seorang anggota masyarakat sedikit demi sedikit belajar adat istiadat, kebudayaan, pola hidup, perilaku, dan etika masyarakatnya; dan (d) Fungsi kontrol sosial. Bahasa berfungsi untuk mempengaruhi sikap dan pendapat orang lain. Apabila fungsi ini berlaku dengan baik, maka semua kegiatan sosial akan berlangsung dengan baik pula.

\section{Jenis dan Kemampuan Berbahasa Perkembangan berbahasa}

Pengertian bahasa menurut Yamin (2010:137) menyatakan bahwa pada aspek pengembangan bahasa, kompetensi dan hasil yang diharapkan adalah anak mampu menggunakan bahasa sebagai pemahaman bahasa pasif dan dapat berkomunikasi secara efektif yang bermanfaat untuk berfikir dan belajar dengan baik.

\begin{tabular}{lrr}
\multicolumn{1}{c}{ Selanjutnya Tarigan } & $(1998: 1)$ \\
mengemukakan bahwa & setiap \\
keterampilan itu erat & sekali \\
hubungannya dengan tiga keterampilan \\
lainnya dengan cara yang beraneka \\
ragam. Dalam memperoleh \\
keterampilan berbahasa, biasanya \\
melalui suatu hubungan urutan yang
\end{tabular}

teratur. Mula-mula pada masa kecil belajar menyimak bahasa, kemudian berbicara, sesudah itu belajar membaca dan menulis. Menyimak dan berbicara dipelajari sebelum memasuki sekolah. Keempat keterampilan tersebut pada dasarnya merupakan satu kesatuan, merupakan catur tunggal. Setiap keterampilan itu erat pula berhubungan dengan proses-proses berpikir yang mendasari bahasa. Bahasa seseorang mencerminkan pikirannya. Semakin terampil, seseorang berbahasa, semakin cerah dan jelas jalan pikirannya. Keterampilan hanya dapat diperoleh dan kuasai dengan jalan praktek dan banyak latihan. Melatih keterampilan berbahasa hanya dapat diperoleh dan kuasai dengan jalan praktek dan banyak latihan. Melatih keterampilan berbahasa berarti pula melatih keterampilan berpikir.

Santosa, dkk menyatakan bahwa berbicara adalah mengungkapkan gagasan dan perasaan, menyampaikan sambutan, berdialog, menyampaikan pesan, bertukar pengalaman, menjelasakan, mendeskripsikan dan bermain peran. Berbicara merupakan keterampilan berbahasa yang produktif. Keterampilan ini sebagai implementasi dari hasil simakan. Peristiwa ini berkembang pesat pada kehidupan anak-anak. Hal itu tampak dari penambahan kosa kata yang disimak anak dari lingkungan semakin hari semakin bertambah pula.

Kemudian Mustafa, dkk (2006:4) menyatakan bahwa berbicara adalah proses menyampaikan pesan melalui bahasa lisan, kaitan antara pesan dan bahsa lisan sebagai media penyampaian sangat erat. Pesan yang disampaikan pembicara kepada pendengar tidak dalam bentuk tulisan, tetapi dalam bentuk bunyi bahasa. Pendengar kemudian mengalihkan pesan dalam 
bentuk bunyi bahasa itu menjadi bentuk semula

Berdasarkan pendapat-pendapat yang telah dipaparkan, maka dapat ditarik suatu kesimpulan bahwa berbicara adalah suatu proses penyampaian pesan (ide-ide atau gagasan, maksud) dari seseorang kepada orang lain dalam bentuk bunyi bahasa. Dengan kata lain berbicara tidak hanya sebatas pengucapan bunyi-bunyi atau kata-kata. Berbicara adalah suatu alat untuk mengkomunikasikan gagasan-gagasan yang disusun serta dikembangkan sesuai dengan kebutuhan-kebutuhan sang pendengar.

Menurut Depdiknas (2007:15) mengemukakan bahwa perkembangan berbahasa merupakan kemampuan anak untuk berkomunikasi secara lisan dengan orang lain. Kemampuan ini memberikan gambaran tentang kesanggupan anak menyusun berbagai kosa kata yang telah dikuasai menjadi suatu rangkaian pembicaraan secara berstruktur. Termasuk dalam kemampuan ini adalah: (1) Menggunakan dan dapat menjawab pertanyaan apa, berapa, di mana, mengapa dan bagaimana secara sederhana; (2) Bicara lancar dengan kalimat sederhana; (3) Bercerita tentang kejadian disekitarnya secara sederhana; (4) Menjawab pertanyaan tentang cerita pendek, 5-6 kalimat yang sudah diceritakan guru; (5) Bercerita dengan kata ganti aku atau saya; (6) Memberikan keterangan atau informasi tentang suatu hal; (7) Memberikan batasan tentang kata/benda; dan (8) Menjawab pertanyaan tentang keterangan atau informasi secara sederhana.

Bila dicermati kemampuan berbahasa pada anak usia dini tersebut di atas, diketahui bahwa anak telah mulai dilatih untuk berbicara atau berkomunikasi agar mereka dapat dapat berinteraksi dengan yang lainnya. Melalui kemampuan ini anak dapat menyampaikan pesan-pesan atau menerima pesan dari orang lain.

Demikian juga halnya dalam Depdiknas (2007:3) bahwa kemampuan berbahasa tidak selalu ditunjukkan oleh kemampuan membaca saja, tetapi juga kemampuan lain seperti penguasaan kosa kata, pemahaman, dan kemampuan berkomunikasi. Perkembangan kemampuan berbahasa anak usia 5-6 tahun ditandai oleh berbagai kemampuan sebagai berikut: Mampu menggunakan kata ganti saya dalam berkomunikasi; (2) Memiliki berbagai perbendaharaan kata kerja, kata sifat, kata keadaan, kata tanya dan sambung; (3) Menunjukkan pengertian dan pemahaman tentang sesuatu; (4) Mampu mengungkapkan pikiran, perasaan dan tindakan dengan menggunakan kalimat sederhana; dan (5) Mampu mengungkapkan sesuatu melalui gambar.

Berdasarkan pendapat di atas dapat disimpulkan bahwa bahasa merupakan sarana yang paling penting dalam komunikasi manusia. Dalam kenyataan kegiatan sehari-hari kita amati bahwa hanya manusialah yang mampu menggunakan komunikasi verbal dan kita amati pula bahwa manusia mampu mempelajarinya. Jadi, keterampilan yang harus di miliki anak mencakup 4 keterampilan berbahasa yaitu menyimak atau mendengarkan atau menyimak, berbicara, menulis, dan membaca. Namun dalam hal ini penulis hanya membatasi pada hal menyimak saja.

\section{Kemampuan Menyimak}

Menurut pendapat Mukhtar (2006:2), menyatakan bahwa menyimak 
merupakan bagian dari empat komponen bahasa. Menyimak merupakan komponen bahasa tingkatan pertama. Sejak manusia masih dalam kandungan proses menyimak sudah mulai berlangsung. Hal ini dapat diterima di mana para ibu-ibu yang sedang hamil dianjurkan untuk memperdengarkan musik-musik lembut yang berisi ajaran moral yang positif agar si cabang bayi terbiasa dan peka terhadap apa yang didengarnya.

Pada proses menyimak ada unsur kesengajaan bahkan telah dipersiapkan terlebih dahulu tantang apa saja yang akan menjadi fokus perhatian terhadap apa yang disimak. Dalam peristiwa menyimak, unsur pemahaman, interpretasi, bahkan analisis dan penilaian dilakukan oleh orang yang menyimak.

Peristiwa menyimak akan melalui dua proses sebelumnya yaitu proses mendengar dan mendengarkan. Lebih jauh menyimak dapat didefinisikan sebagai suatu proses menyerap informasi yang dilakukan malalui beberapa tahapan yaitu mendengarkan, memahami, menginterpretasi, menilai, dan memberikan respon terhadap apa yang disimak. Peristiwa menyimak melibatkan pendengaran, penglihatan, penhayatan, ingatan, pengertian, bahkan hati nurani juga terlibat dalam peristiwa menyimak.

Menyimak bermakna mendengarkan dengan penuh pemahaman dan perhatian, apresiasi, serta interpretasi untuk memperoleh informasi, menangkap ide atau pesan serta memahami makna kemunikasi yang telah disampaikan oleh sang pembicara melalui ujaran atau bahasa lisan.

Kemudian menurut Tarigan (2001:27) menyatakan bahwa menyimak adalah suatu proses yang mencakup kegiatan mendengar, mengidentifikasi, menginterprestasi bunyi bahasa emudian menilai hasil interprestasi makna dan menanggapi pesan yang tersyirat di dalam wahana tersebut. Dalam bahasa yang mudah lagi sederhana menyimak berarti kemampuan memahami pesan yang disampaikan melalui bahasa lisan.

Dengan kata lain menyimak cerita berarti mendengarkan dengan penuh pemahaman dan perhatian, apresiasi, serta interpretasi untuk memperoleh informasi, menangkap ide atau pesan serta memahami makna kemunikasi yang telah disampaikan oleh sang pembicara dalam hal ini orang yang menyampaikan cerita melalui ujaran atau bahasa lisan.

Sebagaimana dikemukakan pada bagian awal bahwa menyimak merupakan suatu kegiatan berbahasa, berbicara tentang proses tentu melalui proses atau tahap-tahapan. Razak (2003:4) menyatakan bahwa dalam hal menyimak akan dilalui beberapa tahapan sebagai berikut: (1) Tahap mendengarkan (hearing), pada tahap ini penyimak baru mendengarkan pembicaraan seseorang; (2) Tahap memahami (understanding), setelah mendengarkan suatu tuturan atau pembicaraan, penyimak melalukan tahap yang lebih tinggi yakni memahami apa yang disampaikan oleh pembicara; (3) Tahap menginterpretasi, pada tahap ini si penyimak akan melakukan interpretasi, penafsiran terhadap fakta yang disimaknya. Seorang penyimak yang baik tidak bisa menerima begitu saja apa yang didengarnya tetapi harus ditafsirkan terlebih dahulu sebelum memutuskan untuk mengikuti apa yang disimaknya; (4) Tahap menilai (evaluating), setelah memahami, menafsirkan isi pembicaraan, penyimak melanjutkan ke tahap penilaian gagasan yang dikemukakan pembicara. Dalam tahap penilaian ini, penyimak sudah menimbang kelemahan, kelebihan apa 
yang dituturkan seseorang dengan berbagai acuan atau standar yang telah ditetapkan penyimak; dan (5) Tahap menanggapi (responding), merupakan tahap yang paling tinggi dalam proses menyimak di mana penyimak menyambut, mencamkan, menyerap melalui empat proses sebelumnya. Dengan demikian pada tahap menanggapi ini merupakan tahap memutuskan untuk diterima atau ditolah apa yang sudah disimak.

Dari uraian di atas, dapat dimanifestasikan bahwa dalam menyimak cerita terdapat tahapantahapan mendengarkan, mengerti/ mamahami, tahap menginterpretasi, tahap menilai, dan tahap menanggapi terhadap cerita yang dibacakan.

\section{Media Sketsa}

Dalam pendidikan kita sering mendengar kata media pendidikan dan media pembelajaran. Para guru saat menyajikan bahan pelajaran di depan kelas sering menggunakan media pembelajaran. Penggunaan media seperti itu bertujuan agar informasi pembelajaran yang dsampaikan guru dapat diterima dengan baik oleh siswa, sehingga terjadi perubahan-perubahan perilaku seperti pengetahuan, sikap maupun keterampilan.

Arief S. Sadiman dkk (2009:33) mengemukakan bahwa," kata media berasal dari bahasa latin dan merupakan bentuk jamak dari kata medium yang secara harfiah berarti perantara atau pengantar pesan dari pengirim ke penerima pesan. Banyak batasan yang diberikan orang tentang media Asosiasi Tekhnologi dan Komunikasi Pendidikan (Associationfor Educational Communication and Technology /AECT) di Amerika, membatasi media sebagai segala bentuk dan saluran yang digunakan orang untuk menyalurkan pesan /informasi.

Menurut Heinich dalam Neviyarnis (2005:4) mengemukakan medium sebagai perantara yang mengantar informasi antara sumber dan informasi, misalnya televisi, film, foto, radio, rekaman audio, gambar yang diproyeksikan, bahan-bahan cetakan dan sejenisnya adalah media komunikasi.

Selanjutnya menurut Rosii dan Breidle dalam Wina Sanjaya (2012:58) mengemukakan bahwa media pembelajaran adalah seluruh alat dan bahan media pembelajaran yang dapat dipakai untuk tujuan pendidikan seperti radio, televisi, buku, koran, majalah dan sebagainya.

Lebih lanjut Rossi dalam Wina Sanjaya (2012:58) mengemukakan bahwa alat-alat semacam radio dan televisi kalau digunakan dan diprogram untuk pendidikan maka merupakan media pembelajaran. Bagi Rossi media itu sama dengan alat-alat fisik yang mengandung informasi dan pesan pendidikan. Senada dengan pendapat tersebut, pandangan Gagne (dalam Wina Sanjaya, 2012:60) mengungkapkan bahwa media pembelajaran adalah berbagai komponen yang ada dalam lingkungan siswa yang dapat merangsangnya untuk belajar.

Gagne dalam Arief S. Sadiman dkk, (2009:33) menyatakan bahwa media adalah berbagai jenis komponen dalam lingkungan anak yang dapat merangsangnya belajar.

Sementara itu Briggs juga dalam Arief S. Sadiman dkk (2006:6) berpendapat bahwa media adalah segala alat fisik yang dapat menyajikan pesan serta merangsang anak untuk belajar, buku, filem, kaset, filem bingkai adalah contoh-contohnya. 
Asosiasi Pendidikan Nasional (National Education Association/NEA) memiliki pengertian yang berbeda. Media adalah bentuk komunikasi baik tercetak maupun audio visual serta peralatannya. Media hendaknya dapat dilihat, didengar dan dibaca dalam Arief S. Sadiman dkk (2006:7). Sedangkan menurut Azhar Arsyad (2006:4) secara sederhana media diartikan sebagai alat yang menyampaikan atau pesan-pesan pembelajaran.

Bila cermati beberapa pengertian di atas, ada persamaan diantara batasan-batasan tersebut yaitu bahwa media adalah segala sesuatu yang dapat digunakan untuk menyalurkan pesan dari pengirim ke penerima sehingga dapat merangsang pikiran, perasaan, minat serta perhatian anak sedemikian rupa sehingga proses belajar menjadi lebih hidup.

Selanjutnya Sadiman (2009:28) mengungkapkan bahwa karakteristik beberapa jenis media yang lazim digunakan dalam kegiatan pembelajaran di Indonesia salah satunya media grafis. Sementara jenis media grafis adalah: (a) Gambar atau foto; (b) Sketsa; (c) Diagram; (d) Bagan/ Cart; (f) Grafik; dan (f) Kartun dan poster.

Dalam penelitian ini difokuskan pada media sketsa, yaitu gambar yang sederhana, atau draft kasar yang melukiskan bagian - bagian pokoknya tanpa detail. Karena setiap orang yang normal dapat belajar menggambar, setiap guru yang baik haruslah dapat menuangkan ide-idenya ke dalam bentuk sketsa. Sketsa selain dapat menarik perhatian murid, menghindari verbalisme dan dapat memperjelas penyampaian pesan, harganyapun tak perlu dipersoalkan sebab media ini dibuat langsung oleh guru (Sadiman, 2009:28).
Sadiman, dkk

(2009:33) menegaskan bahwa seorang guru bisa saja menerangkan misalnya proses perkembangbiakan kupu-kupu secara lisan atau verbal. Kalau ingin lebih jelas tentu saja sebaiknya menunjukkan benda-benda yang sebenarnya kupukupu, telur, ulat, kepompong serta prose situ sendiri. Kalau itu tidak mungkin, guru bias menunjukkan gambar atau fotonya, tapi itu memerlukan waktu dan biaya. Untuk itu sketsa dapat dibuat secara cepat sementara guru menerangkan dapat pula dipakai untuk tujuan tersebut.

Dengan demikian dari paparan di atas dapat disimpulkan bahwa media sketsa adalah suatu alat yang digunakan guru dari gambar yang sederhana atau draf kasar yang melukiskan bagianbagian pokoknya tanpa detail.

\section{Penggunaan Media Sketsa Dalam Pembelajaran}

Dalam aktivitas pembelajaran, pengajar dapat menjelaskan sesuatu secara lisan atau verbal. Apabila pengajar ingin penjelasannya lebih jelas dan dapat menarik perhatian pembelajar, sebaiknya pengajar menunjukkan benda-benda sebenarnya. Tetapi apabila pengajar tidak dapat menunjukkan benda-benda sebenarnya, dapat menunjukkan gambar atau foto dari benda-benda sebenarnya, tetapi langkah ini memerlukan waktu dan biaya yang lebih banyak, maka pilihan menggunakan sketsa, adalah merupakan alternative yang menguntungkan dalam proses pembelajaran, sebab selain dapat dibuat pengajar sendiri secara langsung dan cepat.

Gambar skesta merupakan gambar ide awal untuk mengekspresikan gagasan tertentu ke dalam gambar disain. Merangkum aspek-aspek disain 
gambar awal yang memerlukan olahan lebih lanjut. Gambar sketsa merupakan sarana komunikasi awal untuk perancang (yang menggambar) maupun orang lain. Menggambar sketsa pada dasarnya adalah menarik garis dengan tangan bebas, tanpa dibantu mistar atau penggaris. Dengan demikian kualitas garis harus diperhatikan sesuai dengan karakter dan jenis gambar yang akan disajikan. Kualitas garis yang dibuat oleh pinsil akan ditentukan oleh tingkat kehitaman (ketebalan) garis dan lebar garis. Pada gambar sketsa, semua garis harus dimulai dan diakhiri dengan tegas dan harus mempunyai kaitan yang logis dengan garis lainnya dari awal sampai akhir. Bila dua garis membentuk sudut atau perpotongan, kedua ujungnya harus bertemu, tidak boleh kurang atau lebih

Langkah-langkah untuk membuat sketsa menurut Nurbiana Dhieni (2006) adalah guru menyiapkan alat peraga, guru menyuruh anak mengatur posisi tempat duduk, guru memerintahkan anak menyebutkan judul cerita, guru menyebutkan judul cerita yang sebenarnya sambil bercerita, guru menggambar isi cerita atau cotoh cerita secara berurutan, setelah selesai bercerita, guru memperlihatkan gambar keseluruhannya, guru menyuruh anak menyimpulkan isi cerita, guru melengkapi kesimpulan cerita.

\section{Hakikat Media}

Nana Sudjana

(2005:05)

mengatakan bahwa penggunaan media tidak dilihat atau dinilai dari segi kecanggihan medianya, tetapi yang lebih penting adalah fungsi dan peranannya dalam membantu mempertinggi proses pengajaran.

Oleh sebab itu, penggunaan media pengajaran sangat tergantung kepada tujuan pengajaran, bahan pengajaran, kemudahan memperoleh media yang diperlukan serta kemampuan guru dalam menggunakanya dalam proses pengajaran.

Menurut Musfiroh (2005 : 144), pentingnya suatu media gambar antara lain: (1) Karena media dapat digunakan untuk jumlah yang lebih besar karena memiliki daya jangkau yang lebih luas; (2) Karena Perhatian anak dan guru terfokus pada gambar sehingga memudahkan guru untuk mensinkronkan gambar seri dan cerita; (3) Karena dengan adanya media guru lebih leluasa memanfaatkan dengan media untuk keperluan penunjukan objek-objek tertentu dalam gambar; (4) Karena dengan adanya media bagi anak dapat memudahkan mereka melihat dan menginterprestasikan serta memahami cerita yang dibawakan guru; (5) Karena media dapat membuat anak-anak juga memiliki kesempatan untuk memperhatikan gerak tangan, mimik, dan gerak mulut guru ketika bercerita sehingga anak memahami makna dan maksud cerita; (6) Media dapat membantu guru memperkenalkan kata baru kepada anak, terutama kata benda (nomina) yang merujuk pada benda konkret seperti nama hewan, tumbuhan, benda-benda, serta kata kerja yang merujuk pada aktivitas fisik, seperti mencakar, memanjat, menyeret, dan juga adjektif yang merujuk pada perasaan seperti sedih, takut, dan marah; dan (7) Media juga penting karena dapat membantu menggiring imajinasi anak.

\section{Tujuan Media Pengajaran}

Menurut R. Ibrahim (2003:112) bahwa media pengajaran diartikan sebagai segala sesuatu yang dapat digunakan untuk menyalurkan pesan atau isi pelajaran, merangsang pikiran, perasaan, perhatian dan kemampuan 
siswa, sehingga dapat mendorong proses belajar. Pada tahun 50-an, media disebut sebagai alat bantu audio-visual karena pada masa itu peranan media memang semata-mata untuk membantu guru dalam mengajar. tetapi kemudian, namanya lebih populer sebagai media pengajaran atau media belajar.

Lebih lanjut R. Ibrahim (2003:112) mengemukakan berbagai bentuk media dapat digunakan untuk meningkatan pengalaman belajar ke arah yang lebih kongkret. Pengajaran dengan menggunakan media tidak hanya sekedar menggunakan kata-kata (simbol verbal), sehingga dapat diharapkan diperolehnya hasil pengalaman belajar yang lebih berarti bagi siswa. Dalam hal ini Gagne dan Briges menekankan pentingnya media sebagai alat bantu untuk merangsang belajar mengajar. Usaha membuat pengajaran lebih kongkrit dengan menggunakan media banyak dilakukan orang. Berbagai jenis media memiliki nilai dan kegunaan masing-masing. Untuk memahami penggolongan berbagai jenis media berdasarkan nilai yang dimiliki masing-masing.

Berdasarkan penjelasan di atas jelaslah bahwa media pengajaran sangat berfungsi dan penting dalam proses belajar mengajar. Media pengajaran dapat menstimulasi belajar siswa atau membantu siswa terutama untuk mengkongkretkan berbagai konsepnya yang sifatnya abstrak. Melalui media siswa lebih termotivasi untuk belajar, karena siswa berusaha memahami suatu materi pelajaran secara lebih nyata (kongkret).

\section{METODE}

Penelitian ini dilaksanakan di TK Islam Bina Insan Kamil Kecamatan Bukit
Raya Pekanbaru. Jumlah siswa ada sebanyak 23 orang anak, 10 orang lakilaki dan 13 orang perempuan. Penelitian ini dilaksanakan pada semester II tahun ajaran 2013/2014 bulan April-Juli sesuai dengan kurikulum yang berlaku. Penelitian yang penulis laksanakan ini menerapkan 2 siklus melalui tahapantahapan untuk melihat perkambangan bahasa anak melalui media sketsa. Penelitian ini merupakan penelitian tindakan kelas yang dikemukakan oleh Arikunto (2008) mencakup 4 aspek tahapan, yakni: (1) perencanaan; (2) pelaksanaan; (3) Pengamatan; dan (4) refleksi.

Adapun data yang digunakan dalam penelitian ini adalah data tentang aktivitas guru, aktivitas siswa dan perkembangan berbahasa anak, yang diperoleh melalui lembar observasi yang telah disediakan. Observasi, yaitu cara pengumpulan data untuk mendapatkan informasi dengan cara pengamatan langsung terhadap sikap dan prilaku anak.

Aktivitas guru dan anak dinilai berdasarkan skala nilai untuk tiap aspek aktivitas pembelajaran media sketsa (terlampir). Selanjutnya aktivitas guru dan anak selama kegiatan belajar mengajar yang dibukukan pada observasi.

\section{HASIL}

Berdasarkan penjelasan sebelumnya diketahui bahwa tujuan dilakukan perencanaan dalam penelitian ini adalah sebagai acuan atau dasar yang berisikan kegiatan-kegiatan yang berkaitan dengan penelitian penggunaan media sketsa dalam meningkatkan perkembangan bahasa anak usia 5-6 tahun di Taman Kanak-Kanak Islam Bina Insan Kamil Kecamatan Bukit Raya Pekanbaru. Perencanaan ini berisikan kegiatan yang akan dilakukan pada 
tempat penelitian, yaitu a) menetapkan jadwal penelitian yaitu siklus I sebanyak dua kali pertemuan dan siklus II juga dua kali pertemuan.

Dari hasil penelitian pada siklus I menunjukkan bahwa aktivitas belajar anak didik masih tergolong cukup baik dengan skor 289, dengan rata-rata persentase 52,3\%. Sedangkan pada siklus II mencapai skor 424 dengan rata-rata persentase $76,8 \%$. Hal ini disebabkan oleh adanya peningkatan pada aktivitas anak didik pada seluruh indikator.

Secara keseluruhan aktivitas belajar anak di Taman Kanak-Kanak Islam Bina Insan Kamil Kecamatan Bukit Raya Pekanbaru, pada siklus I mencapai rata-rata skor 289 atau $52,3 \%$ dan pada siklus II meningkat menjadi 424 atau $76,8 \%$. Peningkatan untuk seluruh indikator aktivitas belajar anak di Taman Kanak-Kanak Islam Bina Insan Kamil Kecamatan Bukit Raya Pekanbaru sebesar $24,5 \%$.

Rata-rata peningkatan perkembangan bahasa pada anak usia 5-6 tahun dari Data awal ke siklus II adalah atau 34,8\%. Peningkatan Perkembangan bahasa pada anak usia 5-6 tahun dari data awal ke siklus II. Pada Data awal diperoleh skor 278 dengan persentase $37.8 \%$, sedangkan pada siklus II diperoleh skor 556 atau sebesar $75.5 \%$. Dengan demikian terjadi peningkatan sebesar 34.8\%.

Dengan meningkatnya aktivitas anak didik setelah penerapan melalui media sketsa, terlihat pula peningkatan perkembangan bahasa pada anak usia 5-6 tahun di Taman Kanak-Kanak Islam Bina Insan Kamil Kecamatan Bukit Raya Pekanbaru.

Rata-rata Perkembangan bahasa pada anak usia 5-6 tahun pada data awal tercapai $37,8 \%$ dari seluruh jumlah anak, pada siklus pertama meningkat dengan $64,5 \%$ dari seluruh jumlah anak dan pada siklus kedua meningkat dengan $75,5 \%$ dari seluruh jumlah anak yaitu 23 orang.
Aktivitas
guru
dalam

meningkatkan Perkembangan bahasa melalui media sketsa, jika pada siklus I guru sudah melakukan dengan kategori "cukup baik". Hal ini sesuai hasil pengamatan dimana aktivitas guru memperoleh skor 72,9\%. Hasil pengamatan aktivitas guru pada siklus II menunjukkan adanya peningkatan dengan skor 91,7\% dengan kriteria baik.

Peningkatan aktivitas guru dapat meningkatkan aktivitas anak, pada siklus I memperoleh skor 289 (52,3\%) dengan kiteria kurang baik. Terjadi peningkatan aktivitas anak didik pada siklus II dengan skor $424 \quad(76,8 \%)$ dengan kiteria baik. Selain itu peningkatan aktivitas anak didik ini diikuti oleh peningkatan perkembangan bahasa pada anak usia 5-6 tahun dari siklus I ke siklus II. pada siklus I memperoleh skor 475 (64,5\%) dengan kiteria mulai berkembang. Terjadi peningkatan Perkembangan bahasa pada anak usia 5-6 tahun pada siklus II dengan skor $556(75,5 \%)$ dengan kiteria berkembang sangat baik.

Dari data hasil penelitian di atas dapat dikatakan bahwa perkembangan bahasa pada pada setiap anak mengalami peningkatan dari sebelum dilakukannya tindakan penelitian dibandingkan dengan setelah dilakukannya tindakan penelitian melalui media sketsa.

Dalam menerima pembelajaran anak memiliki kemampuan yang berbeda dan di pengaruhi oleh banyak faktor baik yang berasal dari diri anak maupun dari luar. Faktor dari dalam dipengaruh oleh tingkat kemampuan anak yang tidak sama dalam menerima pelajaran. Sedangkan faktor dari luar dipengaruhi oleh media dan metode 
pembelajaran yang digunakan oleh guru. Oleh sebab itu, Sketsa adalah gambar yang sederhana, atau draft kasar yang melukiskan bagian- bagian pokoknya tanpa detail. Dengan menggunakan media sketsa dapat meningkatkan kemampuan berbahasa anak.

Media sketsa dapat diberikan kepada anak sebagai sebuah media untuk meningkatkan kemampuan berbahasa anak di Taman Kanak-Kanak Islam Bina Insan Kamil Kecamatan Bukit Raya Pekanbaru. Media sketsa yang dipaparkan oleh guru akan disukai anak-anak. Hal ini akan menimbulkan rasa penasaran yang terdapat dalam diri anak melalui proses pembelajaran, sehingga guru bisa mengajak mereka belajar mengingat dan menceritakan dalam cara yang sederhana. Dilihat dari kelebihannya metode ini antara lain; anak akan dapat bercerita pada usia sedini mungkin lewat media sketsa, mengembangkan daya ingat otak kanan, melatih kemampuan konsentrasi, dan memperbanyak perbendaharaan kata. Mencermati keadaan ini penulis yakin bahwa penggunaan media sketsa dapat meningkatkan kemampuan anak dalam bebahasa.

Dari hasil penelitian pada siklus I menunjukkan bahwa aktivitas belajar anak didik masih tergolong cukup baik dengan skor 289, dengan rata-rata persentase 52,3\%. Sedangkan pada siklus II mencapai skor 424 dengan rata-rata persentase $76,8 \%$. Hal ini disebabkan oleh adanya peningkatan pada aktivitas anak didik pada seluruh indikator. Secara rinci rekapitulasi aktivitas belajar anak siklus I dan II dapat dilihat pada Tabel 4.7 berikut ini.

Tabel 1

Rekapitulasi Aktivitas Belajar Anak Siklus I dan II

\begin{tabular}{|c|c|c|c|c|c|c|c|}
\hline \multirow[b]{2}{*}{ No } & \multirow{2}{*}{ Aktivitas Anak } & \multicolumn{2}{|c|}{ Siklus I } & \multicolumn{2}{|c|}{ Siklus II } & \multicolumn{2}{|c|}{ Peningkatan } \\
\hline & & Skor & $\%$ & Skor & $\%$ & Skor & $\%$ \\
\hline 1 & $\begin{array}{l}\text { Anak memperhatikan guru menyiapkan } \\
\text { alat peraga }\end{array}$ & 45 & 64.5 & 53 & 76.8 & 9 & 12.3 \\
\hline 2 & Anak mengatur posisi tempat duduk & 37 & 52.9 & 53 & 76.8 & 17 & 23.9 \\
\hline 3 & $\begin{array}{l}\text { Anak diberi kesempatan menyebutkan judul } \\
\text { cerita }\end{array}$ & 34 & 49.3 & 56 & 80.4 & 22 & 31.2 \\
\hline 4 & $\begin{array}{l}\text { Anak mendengarkan judul cerita yang } \\
\text { sebenarnya dari guru }\end{array}$ & 34 & 49.3 & 53 & 76.8 & 19 & 27.5 \\
\hline 5 & Anak memperhatikan dengan seksama & 34 & 49.3 & 52 & 74.6 & 18 & 25.4 \\
\hline 6 & $\begin{array}{l}\text { Setelah selesai bercerita, anak } \\
\text { memperhatikan gambar keseluruhannya }\end{array}$ & 35 & 50.0 & 52 & 75.4 & 18 & 25.4 \\
\hline 7 & Anak menyimpulkan isi cerita & 34 & 49.3 & 51 & 73.2 & 17 & 23.9 \\
\hline 8 & Anak melengkapi kesimpulan cerita & 37 & 53.6 & 56 & 80.4 & 19 & 26.8 \\
\hline & Jumlah & 289 & 418.1 & 424 & 614.5 & 136 & 196 \\
\hline & rata-rata & 36 & 52.3 & 53 & 76.8 & 17 & 24.5 \\
\hline & Kriteria & Kuran & Baik & & & & \\
\hline
\end{tabular}

Sumber: Data Olahan Penelitian, 2013

Berdasarkan tabel diatas maka dapat diketahui bahwa anak memperhatikan guru menyiapkan alat peraga pada siklus I memperoleh skor 45 atau 64,5\% dan meningkat pada siklus II menjadi 53 atau 76,8 \%. 
Peningkatan yang dicapai pada aktivitas anak didik memperhatikan guru menyiapkan alat peraga adalah $12,3 \%$. Anak mengatur posisi tempat duduk pada siklus I memperoleh skor 37 atau $52,9 \%$ dan meningkat pada siklus II dengan skor 53 atau 76,8 \%. Peningkatan yang dicapai pada aktivitas anak didik mengatur posisi tempat duduk adalah 23,9\%. Anak diberi kesempatan menyebutkan judul cerita pada siklus I memperoleh skor 34 atau 49,3 \% dan meningkat pada siklus II dengan skor 56 atau 80,4 \%. Peningkatan yang dicapai pada aktivitas anak didik diberi kesempatan menyebutkan judul cerita adalah 31,2\%. Anak mendengarkan judul cerita yang sebenarnya dari guru pada siklus I mencapai skor 34 atau 49,3 \% dan meningkat pada siklus II menjadi 53 atau $76,8 \%$. Peningkatan yang dicapai pada aktivitas anak mendengarkan judul cerita yang sebenarnya dari guru adalah 27,5\%. Anak memperhatikan dengan seksama yaitu pukulan lembut, pukulan sedang dan pukulan keras. pada siklus I mencapai skor 34 atau 49,36 \% dan meningkat pada siklus II menjadi 52 atau 74,6 \%. Peningkatan yang dicapai pada aktivitas anak memperhatikan dengan seksama adalah 25,4\%. Setelah selesai bercerita, anak memperhatikan gambar keseluruhannya pada siklus I mencapai skor 35 atau 50,0 \% dan meningkat pada siklus II menjadi 52 atau 75,4\%.
Peningkatan yang dicapai pada aktivitas Setelah selesai bercerita, anak memperhatikan gambar keseluruhannya adalah $25,4 \%$.

Anak menyimpulkan isi cerita pada siklus I mencapai skor 34 atau 49,3\% dan meningkat pada siklus II menjadi 51 atau 73,2 \%. Peningkatan yang dicapai pada aktivitas anak menyimpulkan isi cerita adalah 23,9\%. Anak melengkapi kesimpulan cerita, pada siklus I mencapai skor 37 atau $53,6 \%$ dan meningkat pada siklus II menjadi 56 atau 80,4 \%. Peningkatan yang dicapai pada aktivitas anak melengkapi kesimpulan cerita adalah $26,8 \%$.

Secara keseluruhan aktivitas belajar anak di Taman Kanak-Kanak Islam Bina Insan Kamil Kecamatan Bukit Raya Pekanbaru, pada siklus I mencapai rata-rata skor 289 atau $52,3 \%$ dan pada siklus II meningkat menjadi 424 atau 76,8\%. Peningkatan untuk seluruh indikator aktivitas belajar anak di Taman Kanak-Kanak Islam Bina Insan Kamil Kecamatan Bukit Raya Pekanbaru sebesar $24,5 \%$.

Rata-rata peningkatan perkembangan bahasa pada anak usia 5-6 tahun dari Data awal ke siklus II adalah atau 34,8\%. Peningkatan Perkembangan bahasa pada anak usia 5-6 tahun pada sebelum penerapan tindakan (Data awal) dan setelah siklus II dapat dilihat pada Tabel 4.8 berikut ini:

\section{Tabel 2}




\section{Perbandingan Perkembangan bahasa pada anak usia 5-6 tahun Sebelum Penerapan Dengan Siklus II}

\begin{tabular}{|c|c|c|c|c|c|c|}
\hline \multirow{2}{*}{ NO } & \multirow{2}{*}{ Indikator } & \multicolumn{2}{|c|}{ Data Awal } & \multicolumn{2}{|c|}{ Siklus II } & \multirow{2}{*}{ Peningkatan } \\
\hline & & skor & $\%$ & skor & $\%$ & \\
\hline 1 & Mengerti beberapa perintah secara bersamaan & 41 & 44.6 & 74 & 80.4 & 36 \\
\hline 2 & Mengulang kalimat yang lebih kompleks & 34 & 37.0 & 70 & 76.1 & 39 \\
\hline 3 & Menjawab pertanyaan yang lebih kompleks & 32 & 34.8 & 65 & 70.1 & 35 \\
\hline 4 & $\begin{array}{l}\text { Menyebutkan kelompok gambar yang } \\
\text { memiliki bunyi yang sama }\end{array}$ & 36 & 39.1 & 72 & 77.7 & 39 \\
\hline 5 & $\begin{array}{l}\text { Berkomunikasi secara lisan, memiliki } \\
\text { perbendaharaan kata serta mengenal simbol- } \\
\text { simbol untuk persiapan membaca, menulis dan } \\
\text { berhitung }\end{array}$ & 32 & 34.8 & 66 & 71.2 & 36 \\
\hline 6 & $\begin{array}{l}\text { Menyusun kalimat sederhana dalam struktur } \\
\text { lengkap (pokok kalimat-prediket-keterangan) }\end{array}$ & 36 & 39.1 & 73 & 78.8 & 40 \\
\hline 7 & $\begin{array}{l}\text { Memiliki lebih banyak kata-kata untuk } \\
\text { mengekspresikan ide pada orang lain }\end{array}$ & 34 & 37.0 & 68 & 73.4 & 36 \\
\hline 8 & $\begin{array}{l}\text { Melanjutkan sebagian cerita yang telah } \\
\text { diperdengarkan }\end{array}$ & 33 & 35.9 & 71 & 76.6 & 41 \\
\hline & Jumlah & 278 & 302.2 & 556 & 604.3 & 278 \\
\hline & Rata-rata & 34.8 & 37.8 & 69.5 & 75.5 & 34.8 \\
\hline & Kriteria & & & & & \\
\hline
\end{tabular}

Sumber: Data olahan penelitian 2013

Berdasarkan data pada Tabel 4.8 terlihat bahwa terjadi peningkatan Perkembangan bahasa pada anak usia 5-6 tahun dari data awal ke siklus II. Pada Data awal diperoleh skor 278 dengan persentase $37.8 \%$, sedangkan pada siklus II diperoleh skor 556 atau sebesar 75.5\%. Dengan demikian terjadi peningkatan sebesar $34.8 \%$.

Secara keseluruhan Perkembangan bahasa pada anak usia 5-6 tahun pada Data awal siklus I Dan II dapat dilihat pada Tabel berikut ini.

Tabel 3 
Perkembangan bahasa Pada Anak usia 5-6 tahun Pada Data awal Siklus I Dan II

\begin{tabular}{|c|c|c|c|c|c|c|c|}
\hline \multirow{2}{*}{ NO } & \multirow{2}{*}{ Indikator } & \multicolumn{2}{|c|}{ Data Awal } & \multicolumn{2}{|c|}{ Siklus I } & \multicolumn{2}{|c|}{ Siklus II } \\
\hline & & skor & $\%$ & skor & $\%$ & skor & $\%$ \\
\hline 1 & Mengerti beberapa perintah secara bersamaan & 41 & 44.6 & 66 & 71.7 & 74 & 80.4 \\
\hline 2 & Mengulang kalimat yang lebih kompleks & 34 & 37.0 & 61 & 66.3 & 70 & 76.1 \\
\hline 3 & Menjawab pertanyaan yang lebih kompleks & 32 & 34.8 & 56 & 60.3 & 65 & 70.1 \\
\hline 4 & $\begin{array}{l}\text { Menyebutkan kelompok gambar yang } \\
\text { memiliki bunyi yang sama }\end{array}$ & 36 & 39.1 & 60 & 65.2 & 72 & 77.7 \\
\hline 5 & $\begin{array}{l}\text { Berkomunikasi secara lisan, memiliki } \\
\text { perbendaharaan kata serta mengenal simbol- } \\
\text { simbol untuk persiapan membaca, menulis dan } \\
\text { berhitung }\end{array}$ & 32 & 34.8 & 56 & 60.9 & 66 & 71.2 \\
\hline 6 & $\begin{array}{l}\text { Menyusun kalimat sederhana dalam struktur } \\
\text { lengkap (pokok kalimat-prediket-keterangan) }\end{array}$ & 36 & 39.1 & 61 & 66.3 & 73 & 78.8 \\
\hline 7 & $\begin{array}{l}\text { Memiliki lebih banyak kata-kata untuk } \\
\text { mengekspresikan ide pada orang lain }\end{array}$ & 34 & 37.0 & 57 & 61.4 & 67.5 & 73.4 \\
\hline 8 & $\begin{array}{l}\text { Melanjutkan sebagian cerita yang telah } \\
\text { diperdengarkan }\end{array}$ & 33 & 35.9 & 59 & 63.6 & 70.5 & 76.6 \\
\hline & Jumlah & 278.0 & 302.2 & 474.5 & 515.8 & 556.0 & 604.3 \\
\hline & Rata-rata & 34.8 & 37.8 & 59.3 & 64.5 & 69.5 & 75.5 \\
\hline & Kriteria & & & & & & \\
\hline
\end{tabular}

Data Olahan Penelitian, 2013

Dengan meningkatnya aktivitas anak didik setelah penerapan melalui media sketsa, terlihat pula peningkatan perkembangan bahasa pada anak usia 5-6 tahun di Taman Kanak-Kanak Islam
Bina Insan Kamil Kecamatan Bukit Raya Pekanbaru. Peningkatan perkembangan bahasa pada anak juga dapat dilihat pada histogram di bawah ini:

\section{Gambar 1}

Histogram Persentase Perkembangan bahasa pada anak usia 5-6 tahun Pada Data awal, Siklus I Dan II

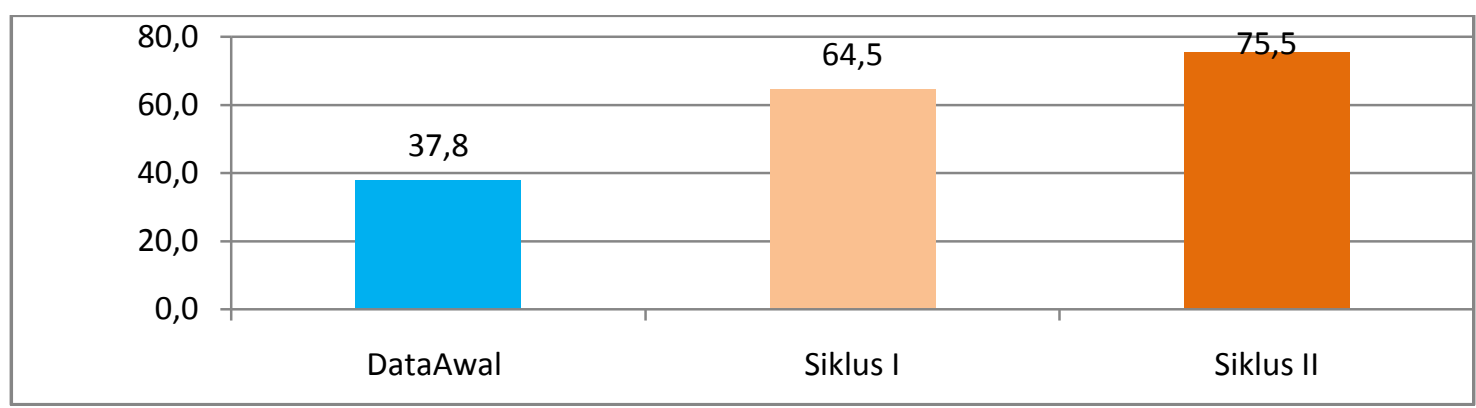


Dari histogram di atas diketahui bahwa rata-rata Perkembangan bahasa pada anak usia 5-6 tahun pada data awal tercapai $37,8 \%$ dari seluruh jumlah anak, pada siklus pertama meningkat dengan $64,5 \%$ dari seluruh jumlah anak dan pada siklus kedua meningkat dengan $75,5 \%$ dari seluruh jumlah anak yaitu 23 orang.

\section{SIMPULAN}

Dari data hasil penelitian di atns dapat dikatakan bahwa perkembangan bahasa pada pada setiap anak mengalami peningkatan dari sebelum dilakukannya tindakan penelitian dibandingkan dengan setelah dilakukannya tindakan penelitian melalui media sketsa

Dalam menerima pembelajaran anak memiliki kemampuan yang berbeda dan di pengaruhi oleh banyak faktor baik yang berasal dari diri anak maupun dari luar. Faktor dari dalam dipengaruh oleh tingkat kemampuan anak yang tidak sama dalam menerima pelajaran. Sedangkan faktor dari luar dipengaruhi oleh media \& metode pembelajaran yang digunakan oleh guru. Oleh sebab itu, Sketsa adalah gambar yang sederhana, atau draft kasar yang melukiskan bagian- bagian pokoknya tanpa detail. Dengan menggunakan media sketsa dapat meningkatkan kemampuan berbahasa anak.

Media sketsa dapat diberikan kepada anak sebagai sebuah media untuk meningkatkan kemampuan berbahasa anak di Taman Kanak-Kanak Islam Bina Insan Kamil Kecamatan Bukit Raya Pekanbaru. Media sketsa yang dipaparkan oleh guru akan disukai anak-anak. Hal ini akan menimbulkan rasa penasaran yang terdapat dalam diri anak melalui proses pembelajaran, sehingga guru bisa mengajak mereka belajar mengingat dan menceritakan dalam cara yang sederhana. Dilihat dari kelebihannya metode ini antara lain; anak akan dapat bercerita pada usia sedini mungkin lewat media sketsa, mengembangkan daya ingat otak kanan, melatih kemampuan konsentrasi, dan memperbanyak perbendaharaan kata. Mencermati keadaan ini penulis yakin bahwa penggunaan media sketsa dapat meningkatkan kemampuan anak dalam bebahasa.

Berdasarkan uraian di atas maka peneliti dapat menentukan hipotesis yang digunakan yaitu Perkembangan bahasa Anak Usia 5 - 6 Tahun di Taman Kanak-Kanak Islam Bina Insan Kamil Kecamatan Bukit Raya Pekanbaru dapat ditingkatkan dengan media sketsa, dapat diterima. Hal ini dapat diketahui dari hasil penelitian dan pembahasan seperti telah diuraikan diperoleh kesimpulan terhadap hasil penelitian ini yaitu: (1) Aktivitas guru dalam penerapan media sketsa pada siklus I guru sudah melakukan dengan kategori "cukup baik". Hal ini sesuai hasil pengamatan dimana aktivitas guru memperoleh skor 72,9\%. Hasil pengamatan aktivitas guru pada siklus II menunjukkan adanya peningkatan dengan skor 91,7\% dengan kriteria baik; (2) Aktivitas siswa kaitannya dengan proses pembelajaran media sketsa memperlihatkan peningkatan seiring dengan peningkatan aktivitas guru. pada siklus I memperoleh skor 289 (52,3\%) dengan kiteria kurang baik. Terjadi peningkatan aktivitas anak didik pada siklus II dengan skor 424 (76,8\%) dengan kiteria baik; dan (3) Perkembangan bahasa Anak Usia 5 - 6 Tahun di Taman Kanak-Kanak Islam Bina Insan Kamil Kecamatan Bukit Raya Pekanbaru pada data awal diperoleh skor 278 dengan persentase $37.8 \%$, pada siklus I memperoleh skor 475 $(64,5 \%)$ dengan kiteria mulai 
berkembang. Terjadi peningkatan Perkembangan bahasa pada anak usia 5-6 tahun pada siklus II dengan skor $556 \quad(75,5 \%)$ dengan kiteria berkembang sangat baik.

\section{DAFTAR RUJUKAN}

Aqib, Zainal. 2009. Belajar dan Pembelajaran Di Taman KanakKanak. Bandung: Yama Widya.

Arikunto, Suharsimi et. al., 2006. Penelitian Tindakan Kelas. Jakarta: Bumi Aksara.

Arsyad, Azhar. 2006. Media Pembelajaran. Jakarta: Raja Grafindo Persada.

Bachri, Bachtiar S., 2005. Pengembangan Kegiatan Bercerita di Taman Kanak-Kanak, Teknik dan Prosedurnya. Jakarta: Depdiknas.

Depdiknas. 2007.

Pedoman Pembelajaran Persiapan Membaca dan Menulis Melalui Pembelajaran di Taman Kanak-Kanak. Jakarta:

Dhieni, Nurbiana. 2006. Metode Pengembangan Bahasa. Jakarta: Universitas Terbuka.

Djago, Tarigan et. al., 2001. Pendidikan Keterampilan Berbahasa. Jakarta: Universitas Terbuka.

Ibrahim, et. al., 2003. Pembelajaran Kooperatif. Universitas Negeri Surabaya.
Mukhtar. 2006. Menyimak. Pekanbaru: Cendikia Insani.

Neviyarni, et. al., 2005. Strategi Pembelajaran. Jakarta: Depdiknas (Pusat teknologi komputer dan informasi pendidikan).

Sadiman, Arief, et. al., 2009. Media Pendidikan Pengertian, Pengembangan, dan Pemanfaatannya. Jakarta: RajaGrafindo Persada

Santosa, Puji, et. al., 2005. Materi dan Pembelajaran Bahasa Indonesia $S D$. Jakarta: Universitas Terbuka.

Santosa, Puji. 2006. Materi dan Pembelajaran Bahasa Indonesia. Jakarta: Universitas Terbuka.

Sudijono, Anas. 2004. Pengantar Statistik Pendidikan. Jakarta. Raja Grafindo Persada.

Sudjana, Nana. 2005. Dasar-dasar Proses Belajar Mengajar. Bandung: Sinar Baru Algensindo.

Razak, Abdul. 2003. Bahasa Indonesia Versi Perguruan Tinggi. Pekanbaru: Autografika.

Wina Sanjaya. 2012. Media Komunikasi Pembelajaran. Jakarta. Kencana.

Yamin, Martinis. 2010. Panduan pendidikan Anak Usia Dini. Jakarta: GP Press. 